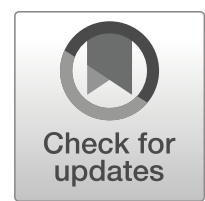

\title{
Updating the saga of the small hive beetle (Aethina tumida): molecular inference of the origin of the South American invasion
}

\author{
Erick Mauricio Goes Cordeiro, Patrícia Lima Soares, Denise Araujo Alves, Alberto Soares CorrêA
}

\begin{abstract}
Department of Entomology and Acarology, Luiz de Queiroz College of Agriculture, University of São Paulo, Av. Pádua Dias, 11, Piracicaba, SP 13418-900, Brazil
\end{abstract}

Received 15 June 2018 - Revised 14 December 2018 - Accepted 15 February 2019

Invasive species / Africanized honey bees / Brazil / COI gene / small hive beetle

In the last three decades, the small hive beetle Aethina tumida Murray 1867 (Coleoptera: Nitidulidae) has drawn attention worldwide after a series of successful invasions into contrastingly different habitats (Lounsberry et al. 2010). The rapid pace at which $A$. tumida is expanding its range has mobilized intensive efforts to understand the source of the invasions, the impact on the local fauna, and how to mitigate this beetle's damage to wild and managed honey bees (Mutinelli et al. 2014). Information about the genetic makeup of an invasive founding population is critical to understand its chances to succeed in a new environment (Lawson Handley et al. 2011). Determining the magnitude and the number of introductions is an important step in assessing the risk to the local fauna as well as the likelihood of admixture of different genetic pools from successive invasions (Andersen et al. 2004). Collection of this type of data is also important in determining gaps in the regulatory control of cross-border movement of goods and products.

Aethina tumida is native to Africa (Neumann and Elzen 2004), where it is considered a minor pest, causing severe damage mainly to weak and stressed bee colonies (Neumann and Ellis 2008). Even though adults can be found in large numbers in honey bee colonies, they have little direct impact. The larvae, on the other

Electronic supplementary material The online version of this article (https://doi.org/10.1007/s13592-019-00636-5) contains supplementary material, which is available to authorized users.

Corresponding author: A. Corrêa, ascorrea@usp.brS. Corrêa, ascorrea@usp.br

Manuscript editor: Peter Rosenkranz hand, may cause serious problems during their development, with heavy damage to the combs (Neumann and Elzen 2004). These beetles can exploit alternative food sources such as fruits (Ellis et al. 2002), which can be an additional concern in tropical regions in terms of management or eradication efforts.

The first introduction of A. tumida was reported in the USA in 1998; the putative route of invasion was through South Carolina and subsequently spreading to Georgia and Florida (Hood 2000). Shortly after this introduction, A. tumida had been reported in 29 states by 2003 (Neumann and Elzen 2004). DNA analysis of mitochondrial COI gene fragments indicated the presence in the USA of two haplotypes, which closely resembled haplotypes in South African populations (Evans et al. 2000, 2003). Subsequently, invasions were reported in Australia (Gillespie et al. 2003), southern Italy (Granato et al. 2017), Mexico and Central America (Neumann et al. 2016), and South America (Al Toufailia et al. 2017). Here, we report the molecular identification of the putative origin of the South American invasion by the small hive beetle. Molecular genetics analyses can help us to understand the timing and magnitude of the original introduction of $A$. tumida into Brazil, as well as serving as a basis for studies on how this alien species adapts to a novel environment, the conditions of its founding, and the chances of the parasite succeeding in following generations.

Specimens of $A$. tumida were collected at the first reported site of infestation in Brazil $\left(22^{\circ} 42^{\prime} 50.14^{\prime \prime} \mathrm{S}, 47^{\circ}\right.$ $37^{\prime} 33.80^{\prime \prime} \mathrm{W}$; Al Toufailia et al. 2017; WAHID interface OIE: http://www.oie.int/wahis/public.ph), from hives of Africanized honey bees in 2018. The fresh samples were 
first identified morphologically upon collection, transferred to tubes containing 95\% $\mathrm{EtOH}$ and stored at $-20{ }^{\circ} \mathrm{C}$. Fourteen beetles were used for DNA extraction. The total genomic DNA was extracted using a modified CTAB method (Doyle and Doyle 1987). The PCRs were performed using specific primers for cytochrome oxidase I (COI) gene fragments of A. tumida forward primer 5'GGTGGATCTTCAGTTGATTTAGC-3' and reverse primer 5'-TCAGCTGGGGGATAAAATTG-3' (Evans et al. 2000) (Supplementary online material S1). Sanger sequencing was conducted in the Animal Biotechnology Laboratory at the University of São Paulo.

In addition to the sequences from beetles sampled in Brazil, 77 A. tumida COI sequences were retrieved from NCBI GenBank database and incorporated in the analysis (Supplementary online material S2). Sequences were edited to $721 \mathrm{bp}$ and aligned with sequences from GenBank database using the ClustalW algorithm in MEGA X (Kumar et al. 2018). The sequences obtained in Brazil were deposited in NCBI GenBank database with the accession numbers (MK286579-MK286592). The software DnaSP 5.10 (Librado and Rozas 2009) was used to define the number of haplotypes that were used in subsequent analyses.

Previous work has demonstrated the presence of two divergent lineages in A. tumida populations (Granato et al. 2017). We performed a phylogenetic analysis including haplotypes of both lineages and an outgroup, Triacanus sp. (NCBI No. KC966655). Bayesian analyses were conducted in MrBayes 3.1.2 (Huelsenbeck and Ronquist 2001), using the GTR+G+I mutation model. The analyses were performed in three runs for

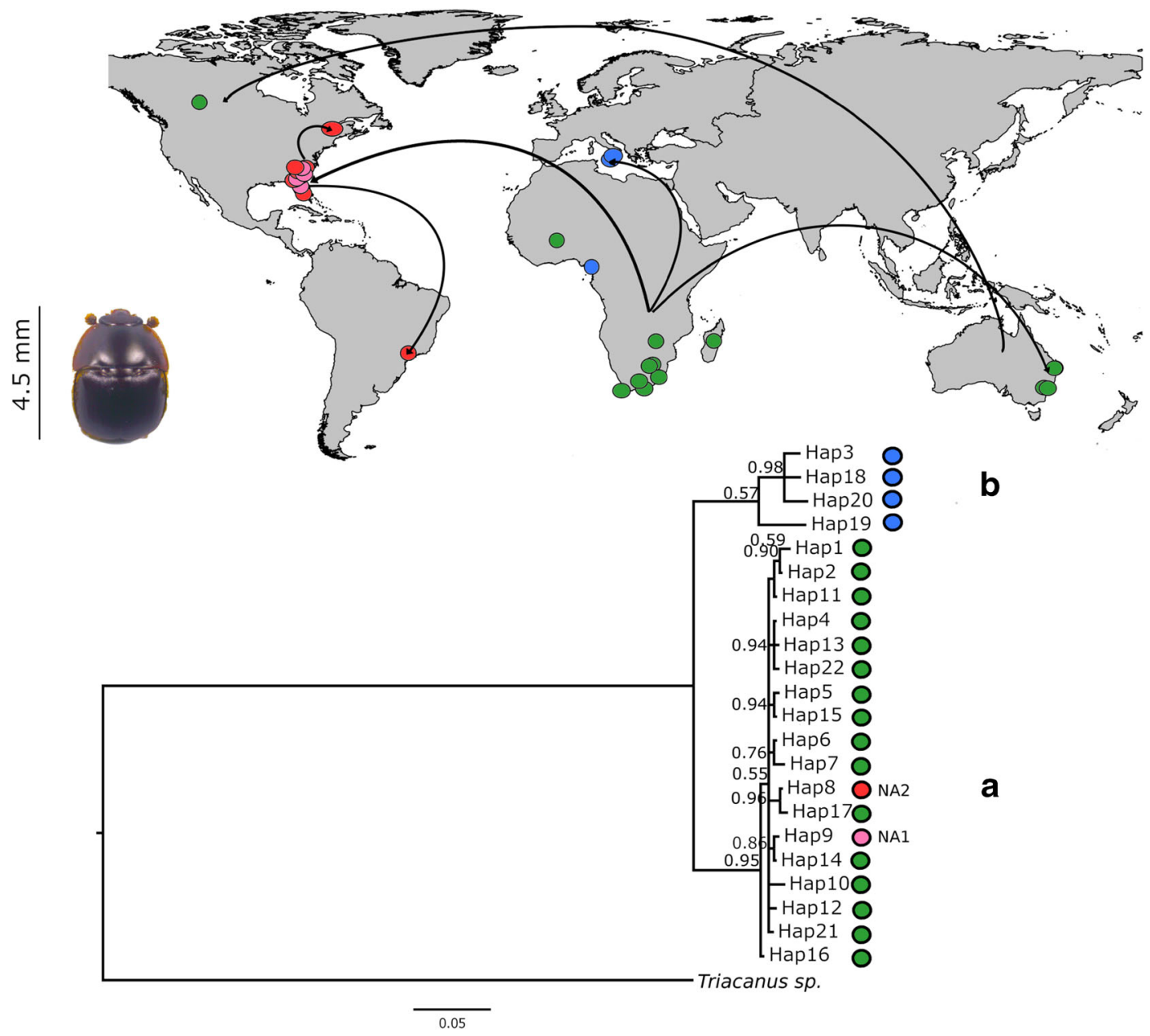

Figure 1. Global geographic distribution and Bayesian phylogenetic relation among COI haplotypes of Aethina tumida (Coleoptera: Nitidulidae). 
$2 \times 10^{6}$ generations, with five chains each and three replications. Trees were sampled every 1000 generations with $25 \%$ burn-in. We have also inferred the evolutionary relation by a maximum likelihood method on MEGA X (Kumar et al. 2018) using the general time-reversible model $(\mathrm{GTR}+\mathrm{G}+\mathrm{I})$ allowing it to run for 10,000 replications.

Characterization of the COI fragment confirmed the presence of $A$. tumida in Brazil via DNA barcoding diagnosis. Sequences from the 14 individuals indicated the presence of a single COI haplotype in Brazil. Haplotype $\mathrm{H} 8$ is identical to one of the two haplotypes present in the USA (NA2) (Evans et al. 2000). At present, 22 different haplotypes have been described worldwide (Figure 1 and Supplementary online material S2), of which two have been found on more than one continent (Figure 1). Both Bayesian and maximum likelihood trees converged to the same tree topology even though branch size and node support differed (Figure 1 and Supplementary online material S3). The most widespread is H4, which has been reported in Australia, South Africa, and Canada (Alberta), followed by H8 which is present in the USA and Canada (Québec) and now in Brazil. Haplotypes H4 and H8 are very similar to haplotypes present in southern Africa, separated only by a few mutational steps. Phylogenetic analysis confirmed the presence of two lineages (A and B) as previously reported by Granato et al. (2017) (Figure 1). The haplotype found in Brazil belongs to group A, which contains the most widely spread haplotypes and has been found on two continents besides Africa.

Specimens of $A$. tumida found in Brazil have the same COI haplotype $(\mathrm{H} 8=\mathrm{NA} 2)$ as the beetles that are present in North America (Evans et al. 2003). Even though it is not conclusive that the source of the introduction was the USA or Canada, the wide genetic diversity and high gene flow observed in southern Africa make it unlikely that Africa was the source of the introduction into Brazil. The presence of two widely dispersed haplotypes in North America (H4 and H8) and the identification of one of these haplotypes in Brazil suggest that a single or a few invasion events of A. tumida originating from the same North American region occurred in Brazil. In North America, populations in Georgia and Florida have strong biases toward $\mathrm{H} 8$, and may be strong candidates as the source of the invasion into Brazil (Evans et al. 2003).

The low haplotype number of North American populations of $A$. tumida does not allow a definitive determination of the exact region of the pest invasion in Brazil. After the initial report of A. tumida in Piracicaba, São Paulo State, subsequent investigations rapidly reported $A$. tumida in honey bee hives in other cities in São Paulo and Rio de Janeiro, raising the question of how widespread A. tumida has become in Brazil. In conclusion, we found strong evidence of a North American origin of the populations of A. tumida in Brazil, probably originating from one or a few invasion events. Further investigations are necessary to understand the population dynamics, as well as to guide immediate control strategies and long-term integrated management of $A$. tumida in this country. The possibility that $A$. tumida might parasitize native stingless bee colonies, as reported for Melipona beecheii in Cuba by Peña et al. (2014), could have an enormous negative impact on Brazilian biodiversity and must be thoroughly investigated.

\section{ACKNOWLEDGMENTS}

We thank São Paulo Research Foundation (FAPESP, fellowship no. 2017/02393-0 to EMGC and grant no. 2014/11495-3 to ASC) and by the Coordenação de Aperfeiçoamento de Pessoal de Nível Superior - Brasil (CAPES) - Finance Code 001 (to DAA and PLS). We also thank Roberto Gaioski Junior who helped with insect sampling.

\section{AUTHORS' CONTRIBUTION}

ASC, DAA, and EMGC conceived and designed the study. EMGC and PLS collected and analyzed the data. ASC provided reagents and analytical tools. ASC, DAA, and EMGC wrote the manuscript. All authors read, corrected, and approved the manuscript.

\section{FUNDING INFORMATION}

Handling Editor: Peter Rosenkranz Contributions: EMGC and PLS collected and analyzed the data. ASC provided reagents and analytical tools. ASC, DAA, and EMGC wrote the manuscript. All authors read, corrected, and approved the manuscript.

\section{COMPLIANCE WITH ETHICAL STANDARDS}

Conflict of interest The authors declare that they have no conflict of interest.

Actualisation de la saga du petit coléoptère des ruches (Aethina tumida): déduction moléculaire sur les origines de l'invasion sud américaine 
Les espèces envahissantes / Abeilles africanisées / Brésil / Gène COI / Petit coléoptère de la ruche

\section{Update der Geschichte des kleinen Beutenkäfers (Aethina tumida): Molekulare Rückschlüsse auf den Urspung der südamerikanischen Invasion}

\section{Invasive Art / Afrikanisierte Honigbienen / Brasilien / COI Gen / Kleiner Beutenkäfer}

\section{REFERENCES}

Al Toufailia H, Alves DA, Bená DdC, Bento JM, Iwanicki NS, Cline AR, Ellis JD, Ratnieks FL (2017) First record of small hive beetle, Aethina tumida Murray, in South America. J Apic Res 56:76-80. https://doi.org/10.1080/00218839.2017.1284476

Andersen MC, Adams H, Hope B, Powell M (2004) Risk assessment for invasive species. Risk Anal 24:787-793. https://doi. org/10.1111/j.0272-4332.2004.00478.x

Doyle JJ, Doyle JL (1987) A rapid DNA isolation procedure from small quantities of fresh leaf tissues. Phytochem Bull 19:11-15.

Ellis JD, Neumann P, Hepburn R, Elzen PJ (2002) Longevity and reproductive success of Aethina tumida (Coleoptera: Nitidulidae) fed different natural diets. J Econ Entomol 95:902-907. https://doi.org/10.1603/0022-0493-95.5.902

Evans JD, Pettis JS, Shimanuki H (2000) Mitochondrial DNA relationships in an emergent pest of honey bees: Aethina tumida (Coleoptera: Nitidulidae) from the United States and Africa. Ann Entomol Soc Am 93:415420 . ht t p s://doi org/10.1603/00138746(2000)093[0415:MDRIAE]2.0.CO;2

Evans JD, Pettis JS, Hood WM, Shimanuki H (2003) Tracking an invasive honey bee pest: mitochondrial DNA variation in North American small hive beetles. Apidologie 34:103-109. https://doi.org/10.1051/apido:2003004

Gillespie P, Staples J, King C, Fletcher MJ, Dominiak BC (2003) Small hive bettle, 'Aethina tumida' (Murray) (Coleoptera: Nitidulidae) in New South Wales. Gen Appl Entomol: J Entomol Soc New South Wales 32:5

Granato A, Zecchin B, Baratto C, Duquesne V, Negrisolo E, Chauzat M-P, Ribière-Chabert M, Cattoli G, Mutinelli F (2017) Introduction of Aethina tumida (Coleoptera: Nitidulidae) in the regions of Calabria and Sicily (southern Italy). Apidologie 48:194-203. https://doi.org/10.1007 /s13592-016-0465-3
Hood WM (2000) Overview of the small hive beetle, Aethina tumida, in North America. Bee World 81:129-137. https://doi.org/10.1080/0005772X.2000.11099483

Huelsenbeck JP, Ronquist F (2001) MRBAYES: Bayesian inference of phylogenetic trees. Bioinformatics 17:754-755. doi: https://doi.org/10.1093/bioinformatics/17.8.754

Kumar S, Stecher G, Li M, Knyaz C, Tamura K (2018) MEGA X: Molecular Evolutionary Genetics Analysis across computing platforms. Molecular Biology and Evolution 35:1547-1549. https://doi.org/10.1093/molbev/msy096

Lawson Handley L-J, Estoup A, Evans D, Thomas C, Lombaert E, Facon B, Aebi A, Roy H (2011) Ecological genetics of invasive alien species. BioControl 56:409-428. https://doi. org/10.1007/s10526-011-9386-2

Librado P, Rozas J (2009) DnaSP v5: a software for comprehensive analysis of DNA polymorphism data. Bioinformatics 25:1451-1452. https://doi.org/10.1093/bioinformatics/btp187

Lounsberry Z, Spiewok S, Pernal SF, Sonstegard TS, Hood WM, Pettis J, Neumann P, Evans JD (2010) Worldwide diaspora of Aethina tumida (Coleoptera: Nitidulidae), a nest parasite of honey bees. Ann Entomol Soc Am 103:671-677. https://doi. org/10.1603/AN10027

Mutinelli F, Montarsi F, Federico G, Granato A, Ponti AM, Grandinetti G, Ferrè N, Franco S, Duquesne V, Rivière M-P, Thiéry R, Henrikx P, Ribière-Chabert M, Chauzat M-P, (2014) Detection of Aethina tumida Murray (Coleoptera: Nitidulidae) in Italy: outbreaks and early reaction measures. J Apic Res 53:569-575. https://doi.org/10.3896/IBRA.1.53.5.13

Neumann P, Ellis JD (2008) The small hive beetle (Aethina tumida Murray, Coleoptera: Nitidulidae): distribution, biology and control of an invasive species. J Apic Res 47:181-183. https://doi.org/10.1080/00218839.2008.11101453

Neumann P, Elzen PJ (2004) The biology of the small hive beetle (Aethina tumida, Coleoptera: Nitidulidae): Gaps in our knowledge of an invasive species. Apidologie 35:229-247. https://oi.org/10.1051/apido:2004010

Neumann P, Pettis JS, Schäfer MO, (2016) Quo vadis Aethina tumida? Biology and control of small hive beetles. Apidologie, 47:427-466. https://doi.org/10.1007/s13592016-0426-x

Peña WL, Carballo LF, Lorenzo JD (2014) Reporte de Aethina tumida Murray (Coleoptera, Nitidulidae) en colonias de la abeja sin aguijón Melipona beecheii Bennett de Matanzas y Mayabeque. Revista de Salud Animal 36:201-204

Publisher's note Springer Nature remains neutral with regard to jurisdictional claims in published maps and institutional affiliations. 